\title{
HAK TERKAIT (NEIGHBORING RIGHT) PELAKU PERTUNJUKAN BERDASARKAN UNDANG-UNDANG NO. 28 TAHUN 2014 TENTANG HAK CIPTA
}

Ni Komang Irma Adi Sukmaningsih, Ratna Artha Windari, Dewa Gede Sudika Mangku

\author{
Jurusan IImu Hukum \\ Universitas Pendidikan Ganesha \\ Singaraja, Indonesia
}

e-mail : \{adi.sukmaningsih, ratnawindari, sudika.mangku\}@undiksha.ac.id

\begin{abstract}
ABSTRAK
Penelitian ini bertujuan untuk (1) mengetahui dan memahami pengaturan hak terkait (neighboring right) dalam memberikan perlindungan terhadap kekayaan intelektual di Indonesia, serta (2) mengetahui akibat hukum terhadap pelanggaran neighboring right bagi pelaku pertunjukan. Jenis penelitian yang digunakan adalah penelitian yuridis normatif. Pendekatan yang digunakan dalam penelitian ini adalah (1) pendekatan perundang- undangan (statute approach), dan (2) pendekatan perbandingan (comparative approach). Data-data yang diperoleh dalam penulisan ini adalah hasil analisis dari (1) Undang-Undang No. 19 Tahun 2002 Tentang Hak Cipta (UU Hak Cipta 2002), (2) Undang-Undang No. 28 Tahun 2014 Tentang Hak Cipta (UU Hak Cipta), (3) copyright act 1988 (Inggris), dan (4) Copyright act (Chapter 63, 1999 Revised Edition (Singapura). Hasil penelitian menunjukkan bahwa (1) pengaturan neighboring right dalam memberikan perlindungan terhadap kekayaan intelektual di Indonesia telah di atur dalam UU Hak Cipta namun masih diperlukan kejelasan terkait hal-hal yang termasuk dalam suatu pertunjukan yang dapat diberikan suatu neighboring right, dan (2) akibat hukum terhadap pelanggaran neighboring right bagi pelaku pertunjukan, secara perdata para pelaku pertunjukan yang dirugikan berhak untuk mengajukan gugatan ganti rugi, sedangkan secara pidana pihak yang melanggar UU Hak Cipta terutama terhadap pelaku pertunjukan dapat dikenai sanksi berupa pidana penjara dan/atau pidana denda.
\end{abstract}

Kata kunci: Neighboring Right, Pelaku Pertunjukan, UU Hak Cipta 


\section{ABSTRACT}

This study aims to (1) know and understand the arrangement of the neighboring right in providing protection for intellectual property in Indonesia and (2) know the legal effect on the contravention of neighboring rights for performers. This research used normative juridical research. The approach that used in this research was (1) statute approach and (2) comparative approach. The research obtained the data from the result of analysis of (1) Act 19 of 2002 on Copyright (Copyright Act 2002), (2) Act 28 of 2014 on Copyright (Copyright Act), (3) Copyright Act 1988 (England), and (4) Copyright Act (Chapter 63, 1999 Revised Edition) (Singapore). This research showed that (1) the arrangement of neighboring right in providing the protection for intellectual property in Indonesia was already regulated in the Copyright Act but it was still necessary to clarify the matters included in the performance that had the possibility to get the neighboring right and (2) due to the law against the contravention of the neighboring right for the performers, based on the civil law the perceived performers who felt aggrieved had the right to claim compensation, whereas based on the criminal law, the criminals of the perceived parties disadvantage could be subject to sanctions in the form of imprisonment or fine.

Keywords: Neighboring Right, Performer, Copyright Act

\section{PENDAHULUAN}

Indonesia adalah salah satu negara yang terkenal akan keanekaragaman budaya serta kekayaan di bidang seni dan sastra dalam mendukung pembangunan bangsa dan memajukan kesejahteraan umum sebagaimana yang diamanatkan oleh Undang-Undang Dasar Negara Republik Indonesia Tahun 1945. Budaya serta kekayaan di bidang seni utamanya di Indonesia sangat beragam, seperti seni musik, seni tari, dan ragam budaya serta seni lainnya yang membuat Indonesia memiliki ciri khas tersendiri yang tidak dimiliki oleh negara lain yang apabila ditampilkan dalam bentuk pertunjukan maka akan menjadi daya tarik bagi pengunjung.

Dalam suatu pertunjukan tentunya terdapat pelaku pertunjukan yang menjalankan suatu kegiatan. Tidak hanya karya seni serta penciptanya saja yang perlu suatu perlindungan. Pelaku pertunjukan pun perlu diberikan perlindungan. Hal ini sebagai salah satu apresiasi terhadap tenaga serta waktu yang diluangkan oleh pelaku pertunjukan dalam menampilkan suatu pertunjukan.

UU Hak Cipta diterbitkan untuk melindungi serta menjamin hak-hak terhadap suatu karya seni yang telah diciptakan. Namun, sering kali perlindungan itu hanya di fokuskan pada karya seni ciptaannya saja tanpa memperhatikan bahwa sebagai pelaku pertunjukan pun berhak atas hak tertentu. Sehingga terlihat jelas bahwa pelaksanaan UU Hak Cipta belum mencapai perlindungan yang menjadi tujuan UU Hak Cipta.

Pada dasarnya, hak cipta adalah sejenis kepemilikan pribadi atas suatu ciptaan yang berupa perwujudan dari suatu ide pencipta di bidang seni, sastra, dan ilmu pengetahuan (Windari, 2017:171).

Kurangnya kesadaran akan urgensi dari neighboring right menjadi indikator dari kurangnya pemahaman para pihak yang berkecimpung dalam kegiatan pertunjukan tersebut yakni pelaku pertunjukan maupun pihak yang menyiarkan serta mengomersialkan pertunjukan tersebut.

Penulisan ini bertujuan untuk memahami dan mengetahui lebih jelas mengenai latar belakang historis dan filosofis lahirnya perlindungan neighboring right terhadap pelaku pertunjukan dalam sistem hukum hak cipta, memahami lebih jelas mengenai akibat hukum terhadap pelanggaran neighboring right bagi pelaku 
pertunjukan, serta untuk memberikan masukan mengenai optimalisasi penerapan neighboring right bagi pelaku pertunjukan di Indonesia.

Berdasar UU Hak Cipta, hak cipta adalah hak eksklusif pencipta yang timbul secara otomatis berdasarkan prinsip deklaratif setelah suatu ciptaan diwujudkan dalam bentuk nyata tanpa mengurangi pembatasan sesuai dengan ketentuan peraturan perundang-undangan. Dalam UU Hak Cipta diatur mengenai dua hal yakni, hak cipta dan hak terkait. Hak cipta berfungsi untuk melindungi hak dari pencipta suatu karya. Sedangkan hak terkait berfungsi melindungi hak dari pelaku pertunjukan.

Pertunjukan merupakan "tontonan yang bernilai seni" yang disajikan sebagai pertunjukan di depan penonton (Murgiyanto, 1996:153). Kata seni pertunjukan mengandung pengertian untuk mempertunjukkan sesuatu yang bernilai seni tetapi senantiasa selalu berusaha untuk menarik perhatian jika disaksikan (Jazuli: 1994: 60).

Pelaku pertunjukan adalah salah satu bagian dari aspek-aspek seni pertunjukan. Semua jenis pertunjukan tentunya memerlukan penyaji sebagai pelaku yang terlihat langsung maupun tidak langsung untuk menyajikan bentuk seni pertunjukan. Berdasarkan UU Hak Cipta, pelaku pertunjukan adalah seseorang atau beberapa orang yang secara sendiri-sendiri atau bersama-sama menampilkan dan mempertunjukan suatu Ciptaan. Para pelaku pertunjukan berhak atas hak yaitu hak terkait, hak inilah yang disebut dengan neighboring right.

Neighboring right adalah mechanical right (hak memperbanyak), performing right (hak mengumumkan), rental right (hak menyewakan), dan moral right (hak moral atas ciptaan dan perubahan yang dilakukan pihak lain). Neighboring right baru diakui oleh internasional di Roma pada tahun 1960 dengan dibentuk suatu konvensi khusus yang mengatur tentang hak terkait ini.
Neighboring right memberikan perlindungan seperti yang diberikan hak cipta. Namun, dapat dikatakan bahwa neighboring right lebih terbatas dan memiliki jangka waktu yang lebih singkat. Para pihak sebagai pemegang neighboring right berhak atas royalti.

Royalti merupakan penjamin hakhak ekonomi dari pencipta dan pelaku pertunjukan. Sebagaimana yang termaktub dalam UU Hak Cipta Pasal 1 Ayat (21) bahwa royalti adalah imbalan atas pemanfaatan hak ekonomi suatu ciptaan atau produk hal terkait yang diterima oleh pencipta atau pemilik hak terkait.

\section{METODE}

Penelitian ini merupakan suatu penelitian yuridis normatif yaitu penelitian yang dilakukan dengan cara meneliti bahan pustaka atau yang disebut dengan penelitian kepustakaan dan ketentuan perundang undangan khususnya terhadap pengaturan neighboring right. Hasil dari penelitian hukum ini adalah memberikan preskripsi mengenai isu hukum yang diajukan. Penelitian ini bertujuan untuk mengetahui bagaimana kondisi perlindungan neighboring right di Indonesia yang tunduk dalam pengaturan UndangUndang No. 28 Tahun 2014 tentang Hak Cipta. Penelitian ini juga bertujuan untuk memberi masukan mengenai norma hukum yang dipandang paling tepat untuk diterapkan dalam melindungi hak pelaku pertunjukan di Indonesia.

Pendekatan yang digunakan dalam penelitian hukum ini adalah:

a. Pendekatan Perundang-undangan (statute approach), diperlukan guna mengkaji lebih lanjut mengenai landasan hukum dengan menelaah undangundang dan regulasi yang bersangkut paut dengan isu hukum yang sedang ditangani (Peter Mahmud Marzuki, 2014:133), yaitu mengenai Neighboring Right Pada Pelaku Pertunjukan Berdasarkan Undang- 
Undang No. 28 Tahun 2014 Tentang Hak Cipta dan juga dikaji berdasarkan perundang-undangan luar negeri yaitu Copyright act 1988 dan Copyright act (Chapter 63, 1999 Revised Edition).

b. Pendekatan Perbandingan (comparative approach) dilakukan dengan membandingkan undang-undang yang mengatur mengenai Hak Cipta pada umumnya dan neighboring right pada khususnya. Dalam penelitian ini pendekatan perbandingan dilakukan dengan membandingkan atara peraturan perundang undangan di Indonesia yaitu Undang -Undang Nomor 28 Tahun 2014 tentang Hak Cipta dengan peraturan perundang undangan di Singapura Copyright act (Chapter 63, 1999 Revised Edition) dan peraturan perundang undangan di Inggris yaitu Copyright act 1988.

Dalam penelitian hukum normatif bahan pustaka merupakan bahan dasar yang dalam ilmu penelitian umumnya disebut dengan bahan hukum sekunder (Soerjono Soekanto dan Sri Mamudji, 2009:24). Dalam bahan hukum sekunder terbagi bahan hukum primer, sekunder, dan tersier.

a. Bahan Hukum Primer

Bahan hukum primer merupakan bahan hukum yang bersifat autoritatif artinya mempunyai otoritas. Adapun bahan hukum primer yang dimaksud terdiri dari:

1) Undang-Undang Nomor 19 Tahun 2002 tentang Hak Cipta

2) Undang-Undang Nomor 28 Tahun 2014 tentang Hak Cipta

3) Copyright act 1988; UndangUndang Hak Cipta 1988

4) Copyright act (Chapter 63, 1999 Revised Edition); UndangUndang Hak Cipta (Bab 63, 1999 Edisi Revisi)

b. Bahan Hukum Sekunder

Bahan hukum sekunder yaitu bahan hukum yang erat kaitannya dengan bahan hukum primer dan dapat membantu menganalisa, memahami, dan menjelaskan bahan hukum primer, yang antara lain adalah buku-buku teks, kamuskamus hukum, jurnal-jurnal hukum, dan komentar-komentar atas putusan pengadilan (Mahmud Marzuki, 2014:181) yang mengulas tentang Neighboring Right pada pelaku pertunjukan menurut UndangUndang No. 28 Tahun 2014 tentang Hak Cipta yang nantinya akan dijadikan sebagai analisis dalam penelitian ini

c. Bahan Hukum Tersier

Bahan hukum tersier, yaitu bahan hukum yang memberikan petunjuk maupun penjelasan atas bahan hukum primer dan bahan hukum sekunder misalnya ensiklopedia atau kamus (Mamudji. 2005:4) serta bahan- bahan lain berupa jurnal, artikel, dan majalah. Bahan hukum dikumpulkan melalui prosedur inventarisasi dan identifikasi peraturan perundang-undangan, serta klasifikasi dan sistematisasi bahan hukum sesuai permasalahan penelitian. Oleh karena itu, teknik pengumpulan data yang digunakan dalam penelitian ini adalah dengan studi kepustakaan.

Begitu isu hukum ditetapkan perlu dilakukan penelusuran untuk mencari bahan-bahan hukum yang relevan terhadap isu yang dihadapi (Mahmud Marzuki, 2014:237). Dalam penelitian ini, yang digunakan adalah pendekatan perundangundangan, dan pendekatan perbandingan untuk memperoleh gambaran yang sistematis dan komprehensif dari bahan hukum primer dan sekunder yang diperoleh untuk menghasilkan preskripsi atau argumentasi hukum yang baru. Untuk itu dalam penelitian ini digunakan teknik deskriptif analisis secara sistematis dan interpretatif untuk mengungkapkan kelemahan, kekurangan, dan kelebihan dari suatu peraturan yang diteliti. Analisis yang dilakukan dalam penelitian ini adalah 
mengidentifikasi mengenai norma kabur yang terdapat dalam Undang-Undang No 28 Tahun 2014 Tentang Hak Cipta.

\section{PEMBAHASAN \\ Pengaturan Neighboring Right dalam Memberikan Perlindungan terhadap Kekayaan Intelektual di Indonesia}

Pengaturan neighboring right di Indonesia secara implisit diatur dalam Undang-Undang Nomor 28 Tahun 2008 tentang Hak Cipta (UU Hak Cipta). Neighboring right pada UU Hak Cipta Pasal 1 Ayat (5) adalah hak yang berkaitan dengan hak cipta yang merupakan hak eksklusif bagi pelaku pertunjukan, produser fonogram, atau lembaga penyiaran. Dikategorikan sebagai pelaku menurut undang-undang ini adalah aktor, penyanyi, pemusik, penari, atau mereka yang menampilkan, memperagakan, mempertunjukkan, menyanyikan, menampilkan, mendeklamasikan, atau memainkan suatu karya musik, drama, tari, sastra, atau seni lainnya.

Hak Cipta maupun neighboring right sebelumnya di atur dalam Undang-Undang No. 19 Tahun 2002 tentang Hak Cipta. Terdapat beberapa perubahan terhadap Undang-Undang No. 19 Tahun 2002 tentang Hak Cipta yang selanjutnya disebut dengan UU Hak Cipta 2002 dengan Undang-Undang No. 28 Tahun 2014 tentang Hak Cipta yang selanjutnya disebut dengan UU Hak Cipta. Salah satu perubahan yang terlihat antara UU Hak Cipta 2002 dan UU Hak Cipta yaitu pengaturan mengenai pelaku pertunjukan. Didalam UU Hak Cipta diatur mengenai pelaku pertunjukan yakni seorang atau beberapa orang yang secara sendiri-sendiri atau bersama-sama menampilkan dan mempertunjukkan suatu ciptaan sebagaimana yang tercantum dalam Pasal 1 Ayat (6) namun dalam UU Hak Cipta 2002 tidak tercantum pengertian dari pelaku pertunjukan. Dalam UU Hak Cipta 2002 belum pula diatur mengenai hak moral dan hak royalti pelaku secara tersendiri tetapi ketentuan mengenai hak moral pencipta berlaku mutatis mutandis terhadap pelaku, sedangkan dalam UU Hak Cipta sudah diatur mengenai hak moral dan hak royalti pelaku dalam pasal tersendiri.

Perubahan undang-undang ini didasari atas implementasi UU Hak Cipta 2002 menimbulkan berbagai permasalahan antara lain, hasil ekonomi atau pendapatan yang dapat diraih para pencipta lagu atau musik atau pemilik hak terkait di Indonesia sangatlah rendah dibandingkan dengan beberapa negara lain. Padahal banyak pihak mengakui potensi Indonesia sangat besar untuk mengembangkan produk berbasis hak cipta, khususnya dibidang lagu atau musik, jauh lebih besar dari negara yang industri lagu atau musiknya sudah maju seperti Jepang, Korea Selatan, dan beberapa negara Eropa. Saat ini perkembangan seni lagu atau musik di Indonesia sangat pesat seiring dengan perkembangan media elektronik. Grup musik Indonesia yang didominasi kaum muda atau remaja beserta lagu atau musik yang dibawakannya ternyata tidak hanya diminati didalam negeri, melainkan juga di negara tetangga Singapura, Malaysia, dan Brunnei Darusalam (Nainggolan, 2011: 1113).

Pergantian UU Hak Cipta 2002 dengan UU Hak Cipta merupakan salah satu upaya negara untuk melindungi hak ekonomi dan hak moral pencipta dan pemilik neighboring right sebagai unsur penting dalam pembangunan kreativitas nasional. Lemahnya pengaturan mengenai hak ekonomi dan hak moral dapat mengurangi bahkan menghilangkan motivasi para pencipta dan pemilik neighboring right untuk berkreasi. Hilangnya motivasi seperti ini akan berdampak luas pada hilangnya kreativitas makro bangsa Indonesia. Bercermin pada negara-negara maju tampak pada perlindungan yang memadai terhadap hak cipta telah berhasil membawa pertumbuhan ekonomi kreatif secara signifikan dan memberikan kontribusi nyata bagi perekonomian dan 
kesejahteraan rakyat sebagaimana yang tercantum dalam penjelasan umum UU Hak Cipta.

Jika dibandingkan dengan UU Hak Cipta 2002, UU Hak Cipta telah memberikan perlindungan yang lebih lengkap bagi pemilik neighboring right. UU Hak Cipta 2002 hanya mengatur beberapa hal mengenai neighboring right yang tercantum pada Pasal 49 yaitu mengenai pengertian pelaku, produser rekaman, dan lembaga penyiaran.

Beranjak dari perkembangan tersebut seharusnya pencipta atau pemilik neightboring right mendapatkan pendapatan yang tinggi yang memiliki hak ekonomi dalam bentuk royalti atas setiap pemutaran atau pun pementasan ciptaan lagu, musik, atau pun tarian. Hal ini tentu saja berkaitan dengan pemungutan royalti yang dilakukan oleh Lembaga Manajemen Kolektif yang selanjutnya disebut LMK berdasar kuasa pencipta atau pemilik neighboring right. Terdapat beberapa LMK di Indonesia diantaranya Yayasam Karya Cipta Indonesia (YKCl), Wahana Musik Indonesia (WAMI), dan (RAI). Serta bagi hak terkait terdapat PAPPRI, ARDI, SELMI, dan ARMINDO yang secara legal sudah mendapatkan izin operasional dari menteri Hukum dan HAM berdasarkan ketentuan Pasal 88 Ayat (2) UU Hak Cipta dan mewakili kepentingan pencipta, pemegang hak cipta, dan/atau pemilik hak terkait (Sihombing, 2017:4)..

Selanjutnya, berdasarkan Pasal 1 Ayat (8) UU Hak Cipta lembaga penyiaran adalah penyelenggara penyiaran, baik lembaga penyiaran publik, lembaga penyiaran swasta, lembaga penyiaran komunitas maupun lembaga penyiaran berlangganan yang dalam melaksanakan tugas, fungsi, dan tanggung jawabnya sesuai dengan ketentuan peraturan perundangundangan merupakan salah satu implementasi penegakan UU Hak Cipta dalah hal hak cipta secara umum dan hak terkait (neighboring right) secara khusus di kalangan lembaga penyiaran.
Royalti adalah imbalan atas pemanfaatan hak ekonomi suatu ciptaan atau produk hak terkait yang diterima oleh pencipta atau pemilik hak terkait.

Pemberian royalti merupakan salah satu bentuk implementasi penegakan UU Hak Cipta serta pengakuan atas hak cipta (copyright) dan hak terkait (neightboring right). Royalti adalah imbalan atas pemanfaatan hak ekonomi suatu ciptaan atau produk hak terkait yang diterima oleh pencipta atau pemilik hak terkait sebagaimana yang tercantum dalam Pasal 1 Ayat (21) UU Hak Cipta. Pasal 20 UU Hak Cipta ditentukn bahwa yang menjadi ruang lingkup neightboring right adalah:

1. Hak moral pelaku pertunjukan;

2. Hak ekonomi pelaku pertunjukan;

3. Hak ekonomi produser fonogram; dan

4. Hak ekonomi lembaga penyiaran

Didasarkan atas ketiga hak diatas terlihat

ada tiga subjek yang menjadi pemegang neightboring right yaitu, pelaku pertunjukan, produser fonogram, dan lembaga penyiaran. Dari ketentuan ini dapat dilihat walaupun ketentuan neightboring right terdapat dalam pengaturan hak cipta, namun terdapat beberapa perbedaan antara hak cipta dan hak terkait, yang hanya diberikan kepada orang-orang tertentu saja. Perbedaan antara keduanya tidak terlalu jelas terlihat, misalnya saja pada sebuah karya pertunjukan musik yang disiarkan oleh lembaga penyiaran misalnya, terdapat dua perlindungan hukum terhadap hak ini.

Dari hal tersebut diatas, perlindungan yang diberikan terhadap pemegang neighboring right adalah:

1. Hak Moral

Hak moral dalam hak cipta disebut sebagai hak yang bersifat asasi sebagai natural right yang dimiliki manusia (Suyud, 2003: 49). Dengan demikian sudah merupakan suatu kewajiban bahwa setiap pelaku pertunjukan harus mendapatkan pengakuan dan perlindungan terhadap hak moral yang terlekat dengan karya ciptanya. Hak moral pelaku pertunjukan diatur dalam 
Pasal 21 UU Hak Cipta yaitu hak yang melekat pada pelaku pertunjukan yang tidak dapat dihilangkan atau tidak dapat dihapus dengan alasan apapun walaupun hak ekonominya telah dialihkan. Sehingga dapat diketahui hak moral tidak hanya diberikan bagi pencipta satu karya tapi juga bagi pemegang neighboring right.

Hak moral pelaku pertunjukan berdasarkan Pasal 22 UU Hak Cipta tersebut meliputi hak untuk :

a. namanya dicantumkan sebagai pelaku pertunjukan, kecuali disetujui sebaliknya.

b. tidak dilakukannya distorsi ciptaan, mutilasi ciptaan, modifikasi ciptaan, atau hal-hal yang bersifat merugikan kehormatan diri atau reputasinya kecuali disetujui sebaliknya.

2. Hak Ekonomi

Menurut Sanusi Bintang, hak ekonomi adalah hak yang berkaitan dengan pemanfaatan secara komersial suatu ciptaan (Bintang, 1998: 4). Berdasarkan Pasal 23 UU Hak Cipta, hak ekonomi dibedakan penjelasannya antara hak ekonomi bagi pencipta atau pemegang hak cipta dan hak ekonomi bagi pelaku pertunjukan. Hak ekonomi bagi pencipta atau pemegang hak cipta berdasarkan Pasal 8 UU Hak Cipta merupakan hak eksklusif pencipta atau pemegang hak cipta untuk mendapatkan manfaat ekonomi atas ciptaan, yang kemudian di dalam Pasal 9 dijelaskan hak ekonomi yang maksud yaitu untuk melakukan :

a. Penerbitan ciptaan;

b. Penggandaan ciptaan dalam segala bentuknya;

c. Penerjemaan ciptaan;

d. Pengadaptasian, pengaransemenan, atau pentransformasian ciptaan;

e. Pendistribusian ciptaan atau salinannya;

f. Pertunjukan ciptaan;

g. Pengumuman ciptaan;

h. Komunikasi ciptaan; dan

i. Penyewaan ciptaan
Sedangkan hak ekonomi pada pelaku pertunjukan diatur dalam Pasal 23 UU Hak Cipta bahwa pelaku pertunjukan memiliki hak ekonomi yang meliputi hak melaksanakan sendiri, memberikan izin, atau melarang pihak lain untuk melakukan:

a. Penyiaran atau komunikasi atas pertunjukan pelaku pertunjukan

b. Fiksasi dari pertunjukannya yang belum difiksasi

c. Penggandaan atas fiksasi pertunjukannya dengan cara atau bentuk apapun

d. Pendistribusian atas fiksasi pertunjukan atau salinannya

e. Penyewaan atas fiksasi pertunjukan atau salinannya kepada publik

f. Penyediaan atas fiksasi pertunjukan yng dapat diakses publik

Dari pasal tersebut dapat disimpulkan bahwa pelaku pertunjukan memiliki hak untuk memberikan izin dan melarang, dalam:

a. Membuat

b. Memperbanyak

c. Menyiarkan dimana terbagi lagi

a) Menyewakan

b) Pertunjukan umum (public performance)

c) Mengkomunikasikan secara langsung (live performance)

d) Mengkomunikasikan secara interaktif

Dengan demikian, apabila penampilan seorang pelaku pertunjukan hendak direkam maka dibutuhkan izin dari pelaku tersebut sebelum perekaman. Begitu pula diperlukannya izin pelaku tersebut apabila rekaman yang berisi penampilan pelaku hendak diperbanyak atau disiarkan. Dimana yang termasuk kegiatan penyiaran suatu rekaman pertunjukan menurut UU Hak Cipta antara lain, tindakan menyewakan, melakukan pertunjukan umum, melakukan komunikasi secara langsung maupun komunikasi secara interaktif. 
Hak cipta berada ditangan pencipta musik sedangkan neighboring right berada ditangan lembaga penyiaran atau pertunjukan karya tari, atau pertunjukan pagelaran musik. Sehingga dapat diketahui bahwa hak cipta terdapat pada si penari (koreografer) sedangkan neighboring right berada di tangan penari yang menunjukkan tariannya di depan umum (Maulana, 2005: 21).

Adanya andil dan ketertiban untuk mendistribusikan karya-karya yang berasal dari hak cipta, tentu saja memberikan manfaat tersendiri bagi si pencipta, yaitu berupa nilai ekonomi dari pencipta. Maka sudah sepatutnya diberikan suatu penghargaan berupa perlindungan hukum dan mendapatkan royalti dari penampilan tersebut manakala penampilan tersebut ditayang ulang (Saidin, $2003: 136$ ).

Berdasarkan UU Hak Cipta ditentukan bahwa masa berlaku hak terkait dibagi menjadi dua yakni masa berlaku hak moral pelaku pertunjukan dan masa berlaku hak ekonomi pelaku pertunjukan, produser fonogram, dan lembaga penyiaran. Sebagaimana yang tercantum dalam Pasal 62 UU Hak Cipta, masa berlaku hak moral pelaku pertunjukan berlaku secara mutatis mutandis terhadap hak moral pelaku pertunjukan. Sedangkan masa berlaku hak ekonomi pelaku pertunjukan, produser fonogram, dan lembaga penyiaran diatur dalam Pasal 63 UU Hak Cipta yaitu pelindungan hak ekonomi bagi pelaku pertunjukan berlaku selama 50 (lima puluh) tahun sejak pertunjukannya difiksasi dalam fonogram atau audiovisual, bagi produser fonogram berlaku selama 50 (lima puluh) tahun sejak fonogramnya difiksasi, dan bagi lembaga penyiaran berlaku selama 20 (dua puluh) tahun sejak karya siarannya pertama kali disiarkan. Masa perlindungan hak ekonomi terhitung mulai tanggal 1 Januari tahun berikutnya.

Dalam hukum Indonesia, pengaturan neighboring right tidak diatur secara rinci dalam peraturan khusus melainkan diatur dalam Undang-Undang No. 28 Tahun 2014 tentang Hak Cipta.

Ketentuan dalam UU Hak Cipta tersebut telah mengakomodasi pengaturan dalam konvensi internasional sebagaimana terdapat dalam Konvensi Roma 1961 dan WIPO Performances and Phonograms Treaty (WPPT).

WPPT memberikan 3 hak tambahan sebagai extra rights kepada performers berupa (Damian, 2009: 91-92):

a. Hak mengontrol perwujudan pertunjukannya yang diperbanyak, diumumkan, disewakan, dan juga mengontrol pemasarannya (Pasal 7 sampai dengan Pasal 10 WPPT);

b. Jika suatu pertunjukan di pertontonkan secara luas kepada publik (public performance), negara peserta WPPT harus menjamin performer menerima pembayaran (Pasal 15 WPPT);

c. Hak moral berupa identitas dan integritas pertunjukan hidup (live performance) para performer atau pertunjukan yang dialihkan dalam wujud rekaman suara harus dijamin negara peserta (Pasal 5 WPPT).

Dalam perkembangannya, pengaturan mengenai neighboring right dalam hal memberikan perlindungan kekayaan intelektual di Indonesia terus di tingkatkan. Hal ini terlihat dari di lakukannya pergantian Undang-Undang mengenai Hak Cipta.

Dalam Penelitian ini UU Hak Cipta dibandingkan dengan aturan asing, yaitu Copyright act 1988 yang berasal dari Inggris dan Copyright act (Chapter 63, 1999 Revised Edition) yang berasal dari Singapura. Penggunaan 2 (dua) aturan ini sebagai pembanding dengan UU Hak Cipta dikarenakan kedua aturan tersebut memiliki pengaturan yang jelas terhadap neighboring right. Jika dianalisis dan kemudian dibandingkan dengan kedua aturan asing tersebut terlihat ada beberapa perbedaan, yakni dalam hal penjelasan mengenai halhal apa saja yang dikategorikan sebagai suatu pertunjukan yang dapat diberikan neighboring right dan yang tidak dapat 
diberikan neighboring right. Didalam UU Hak Cipta jenis-jenis pertunjukan yang dilindungi tidak diatur dalam pasal tersendiri namun ketentuan mengenai pertunjukan berlaku mutatis mutandis terhadap pelaku. Dalam copyright act 1988 sebenarnya tidak jauh berbeda dengan aturan Indonesia dimana aturan ini hanya menjelaskan hal- hal yang termasuk pertunjukan adalah:

a. Pertunjukan berupa drama

b. Pertunjukan musikal

c. Pembacaan atau pembacaan karya sastra

d. Beraneka ragam pertunjukan atau presentasi serupa

Jadi selain hal-hal yang disebutkan diatas maka tidak dikategorikan termasuk dalam suatu pertunjukan. Sedangkan dalam Copyright act (Chapter 63, 1999 Revised Edition). Penampilan yang bukan merupakan suatu pertunjukan adalah :

a. Pertunjukan dalam hal pendidikan

b. Pembacaan, resital atau pengiriman berita dan informasi

c. Pertunjukan kegiatan olahraga

d. Partisipasi dalam pertunjukan sebagai anggota audiens

e. Pertunjukan di sebuah Parade

f. Pertunjukan lain yang ditentukan oleh menteri

Selain itu dalam hal perlindungan hak ekonomi dari ketiga aturan diatas pun terdapat perbedaan. Dalam UU Hak Cipta diatur bahwa perlindungan hak ekonomi bagi pelaku pertunjukan berlaku selama 50 tahun sejak pertunjukannya di fiksasi dalam fonogram atau audiovisual. Dalam copyright act 1988 tidak terlalu berbeda bahwa Perlindungan hak ekonomi yang berhubungan dengan suatu pertunjukan yaitu:

1. 50 tahun sejak pertunjukan tersebut ditampilkan

2. Apabila pertunjukan tersebut direkam maka 50 tahun sejak rekaman tersebut pertama kali di publikasikan, dimainkan, diperlihatkan, atau disediakan pada publik
Sedangkan dalam Copyright act (Chapter 63, 1999 Revised Edition) Periode perlindungan dimulai ketika pertunjukan diberikan dan berakhir pada akhir periode 70 tahun kalender pada saat pertunjukan itu diberikan. Perlindungan ini diberikan waktu yang lebih lama untuk mengapresiasi suatu karya seni atau menghargai pertunjukan yang dilakukan oleh pelaku pertunjukan. Jika dikaitkan dengan teori reward dalam teori perlindungan Hak Kekayaan Intelektual walaupun dalam teori ini hanya dicantumkan bagi pencipta, namun secara tersirat pelaku pertunjukan berhak atas suatu penghargaan atas hasil jerih payahnya dalam menampilkan suatu pertunjukan. Selain itu para pelaku petunjukan telah mengeluarkan tenaga, waktu dan biaya harus diberikan kesempatan mendapatkan kembali apa yang telah dikeluarkan tersebut yang berkorelasi dengan teori recovery dalam teori perlindungan Hak Kekayaan Intelektual.

\section{Akibat Hukum terhadap Pelanggaran Neighboring Right bagi Pelaku Pertunjukan}

Berdasarkan UU Hak Cipta, pemegang hak cipta berhak mengajukan gugatan ganti rugi atas pelanggaran hak ciptanya dan meminta penyitaan terhadap benda yang diumumkan atau hasil perbanyakan ciptaan itu. Pengenaan sanksi terhadap pelanggaran neighboring right ini disamakan dengan pelanggaran hak cipta, hal ini didasarkan pada pertimbangan bahwa kemungkinan adanya kerugian ekonomi dan kerugian lain yang timbul karena pelanggaran terhadap hak-hak yang berkaitan dengan hak cipta tersebut pada dasarnya sama dengan kerugian pada pelanggaran hak cipta. Demikian juga ketentuan-ketentuan lainnya yang diatur dalam UU Hak Cipta diberlakukan juga terhadap pemilik hak-hak yang terkait dengan hak cipta tersebut (Usman, 2003: 152-153).

Sebagaimana yang tercantum pada Pasal 96 UU Hak Cipta bahwa pencipta, 
pemegang hak cipta, dan/atau pemegang hak terkait atau ahli warisnya yang mengalami kerugian hak ekonomi berhak memperoleh ganti rugi. Ganti rugi yang dimaksud kemudian diberikan dan dicantumkan sekaligus dalam amar putusan pengadilan tentang perkara tindak pidana hak cipta dan/atau hak terkait. Pembayaran ganti rugi tersebut dibayarkan paling lama 6 (enam) bulan setelah putusan pengadilan yang berkekuatan hukum tetap.

Selain itu dalam Pasal 98 Ayat (2) disampaikan bahwa pengalihan hak ekonomi pelaku pertunjukan kepada pihak lain tidak mengurangi hak pelaku pertunjukan atau ahli warisnya untuk menggugat setiap orang yang dengan sengaja dan tanpa hak dan tanpa persetujuan pelaku pertunjukan yang melanggar hak moral pelaku pertunjukan. Pasal 52 UU Hak Cipta telah menegaskan bahwa setiap orang dilarang merusak, memusnahkan, menghilangkan, atau membuat tidak berfungsi sarana kontrol teknologi yang digunakan sebagai pelindung ciptaan atau produk hak terkait serta pengaman hak cipta atau hak terkait, kecuali untuk kepentingan pertahanan dan keamanan negara, serta sebab lain sesuai dengan ketentuan peraturan perundangundangan, atau diperjanjikan lain. Apabila hal tersebut dilanggar maka akan masuk ke dalam ranah pidana sesuai Pasal 112 UU Hak Cipta maka akan dijatuhi pidana paling lama 2 (dua) tahun dan/atau pidana denda paling banyak Rp. 300.000.00,00 (tiga ratus juta rupiah).

Selanjutnya dalam Pasal 114 Hak Cipta diatur pula bahwa setiap orang yang mengelola tempat perdagangan dalam segala bentuknya yang dengan sengaja dan mengetahui membiarkan penjualan dan/atau penggandaan barang hasil pelanggaran hak cipta dan/atau hak terkait di tempat perdagangan yang dikelolanya, dipidana dengan pidana denda paling banyak $\mathrm{Rp}$. 100.000.000,00 (seratus juta rupiah). Jadi jelas terlihat bahwa secara perdata para pelaku pertunjukan yang merasa dirugikan berhak untuk mendapatkan ganti rugi dan pihak yang menyebabkan kerugian masuk ke dalam ranah pidana yakni di pidana penjara atau di pidana denda apabila hal tersebut sudah di proses di Pengadilan. Dalam hal ini berdasarkan Pasal 95 Ayat (2) pengadilan yang berwenang dalam mengadili penyelesaian sengketa ini adalah pengadilan niaga, yang kemudian ditegaskan kembali pada Pasal 95 Ayat (3) selain pengadilan niaga, pengadilan lainnya tidak berwenang dalam menangani penyelesaian sengketa hak cipta. Pasal 95 Ayat (3) pula mengatur bahwa selain pelanggaran hak cipta dan/atau hak terkait dalam bentuk pembajakan, sepanjang para pihak yang bersengketa diketahui keberadaannya dan/atau berada di wilayah Negara Kesatuan Republik Indonesia harus menempuh terlebih dahulu penyelesaian sengketa melalui mediasi sebelum melakukan tuntutan pidana.

Para pelaku pertunjukan berhak mengajukan gugatan ganti rugi kepada pengadilan niaga atas pelanggaran hak terkait sesuai pernyataan dalam UU Hak Cipta. Gugatan ganti rugi tersebut dapat berupa permintaan untuk menyerahkan seluruh atau sebagian penghasilan yang diperoleh dari pertunjukan atau pameran karya yang merupakan hasil pelanggaran produk neighboring right. Selain itu para pemilik neighboring right dapat memohon putusan provisi atau putusan sela kepada pengadilan niaga.

\section{SIMPULAN DAN SARAN}

Adapun hal-hal yang dapat penulis simpulkan adalah sebagai berikut :

1. Neighboring right telah diatur dalam peraturan perundang-undangan di Indonesia yakni dalam UndangUndang No. 28 Tahun 2014 tentang Hak Cipta. Hak Cipta maupun neighboring right sebelumnya di atur dalam Undang-Undang No. 19 
Tahun 2002 tentang Hak Cipta. Pergantian UU Hak Cipta 2002 menjadi UU Hak Cipta merupakan salah satu upaya negara untuk melindungi hak ekonomi dan hak moral pencipta dan pemilik neighboring right. Dalam Penelitian ini UU Hak Cipta dibandingkan dengan aturan asing. Aturan asing yang dipergunakan adalah Copyright act 1988 yang berasal dari Inggris dan Copyright act (Chapter 63, 1999 Revised Edition) yang berasal dari Singapura. Penggunaan 2 (dua) aturan ini sebagai pembanding dikarenakan kedua aturan tersebut memiliki pengaturan yang jelas terhadap neighboring right. Jika dibandingkan dengan UU Hak Cipta 2002, UU Hak Cipta telah memberikan perlindungan yang lebih lengkap bagi pemilik neighboring right. Dari ketentuan ini dapat dilihat walaupun ketentuan neightboring right terdapat dalam pengaturan hak cipta, namun terdapat beberapa perbedaan antara hak cipta dan hak terkait, yang hanya diberikan kepada orang-orang tertentu saja. Dengan demikian, apabila penampilan seorang pelaku pertunjukan hendak direkam maka dibutuhkan izin dari pelaku tersebut sebelum perekaman. Begitu pula diperlukannya izin pelaku tersebut apabila rekaman yang berisi penampilan pelaku hendak diperbanyak atau disiarkan. Masa berlaku hak moral pelaku pertunjukan berlaku secara mutatis mutandis terhadap hak moral pelaku pertunjukan. Pelindungan hak ekonomi bagi pelaku pertunjukan berlaku selama 50 (lima puluh) tahun sejak pertunjukannya difiksasi dalam fonogram atau audiovisual. Masa perlindungan hak ekonomi terhitung mulai tanggal 1 Januari tahun berikutnya. Jika dianalisis dan kemudian dibandingkan dengan aturan asing khususnya Copyright act 1988 dan Copyright act (Chapter 63, 1999 Revised Edition), terlihat ada beberapa perbedaan, yakni dalam hal penjelasan mengenai halhal apa saja yang dikategorikan sebagai suatu pertunjukan yang dapat diberikan neighboring right dan tidak dapat diberikan neighboring right dan berkaitan dengan masa perlindungan hak ekonomi bagi pelaku pertunjukan.

2. Akibat hukum terhadap pelanggaran neighboring right bagi pelaku pertunjukan secara perdata yaitu berhak memperoleh ganti rugi. Sedangkan secara pidana apabila terdapat pihak yang melanggar ketentuan UU Hak Cipta dapat dikenai sanksi berupa pidana penjara atau pidana denda.

\section{DAFTAR PUSTAKA}

Anonim, https://ilmuseni.com/senipertunjukan/fungsi-seni-pertunjukan. Diakses Pada 16 September 2017

Black's Law Dictionary, 1990, Sixth Edition, West Publishing

Copyright act (Chapter 63, 1999 Revised Edition)

Copyright act 1988

Damian, Eddy, 2009, Hukum Hak Cipta. Bandung, PT Alumni Bandung

Indonesia, Undang-Undang No. 19 Tahun 2002 Tentang Hak Cipta, Lembaran Negara Republik Indonesia Tahun 2002 Nomor 4220

Indonesia, Undang-Undang No. 28 Tahun 2014 Tentang Hak Cipta, Lembaran Negara Republik Indonesia Tahun 2014 Nomor 266

Mahmud Marzuki, Peter, 2014, Penelitian Hukum Edisi Revisi Cetakan Ke-3, 
e-Journal Komunitas Yustitia Universitas Pendidikan Ganesha Jurusan Ilmu Hukum (Volume 1 No. 1 Tahun 2018)

Jakarta, Kencana Pranada Media Group,.

Mamudji, Sri. 2005. Metode Penelitian dan Penulisan Hukum. Jakarta, Badan Penerbit Fakultas Hukum UI

Margono, Suyud, 2003, Hukum dan Perlindungan Hak Cipta, Jakarta, CV Novindo Pustaka Mandiri

Maulana, Insan Budi, 2005, Bianglala HKI (Hak Kekayaan Intelektual) Ctk. Pertama, Jakarta, Hecca Publishing.

Nainggolan, Bernard, 2011, Pemberdayaan Hukum Hak Cipta dan Lembaga Manajemen Kolektif , Bandung, PT Alumni Bandung

Saidin,H. OK., 2003, Aspek Hukum Hak Kekayaan Intelektual, Jakarta, PT Raja Grafindo Persada
Sihombing, Grace Kelly, 2017, Peran Lembaga Manajemen Kolektif (Studi Di Kota Pontianak). Pontianak:Jurnal Nestor Magister Hukum, Vol. 4 No. 4.

Soekanto, Soerjono dan Sri Mamudji, 2009, Penelitian Hukum Normatif Suatu Tinjauan Singkat, Cetakan ke-11, Jakarta, PT Raja Grafindo Persada.

Usman, Rachmadi, 2003, Hukum Hak Atas Kekayaan Intelektual Perlindungan dan Dimensi Hukumnya di Indonesia, Bandung, PT. Alumni

Windari, Ratna Artha, 2017, Pengantar Hukum Indonesia, Depok : PT RajaGrafindo Persada. 